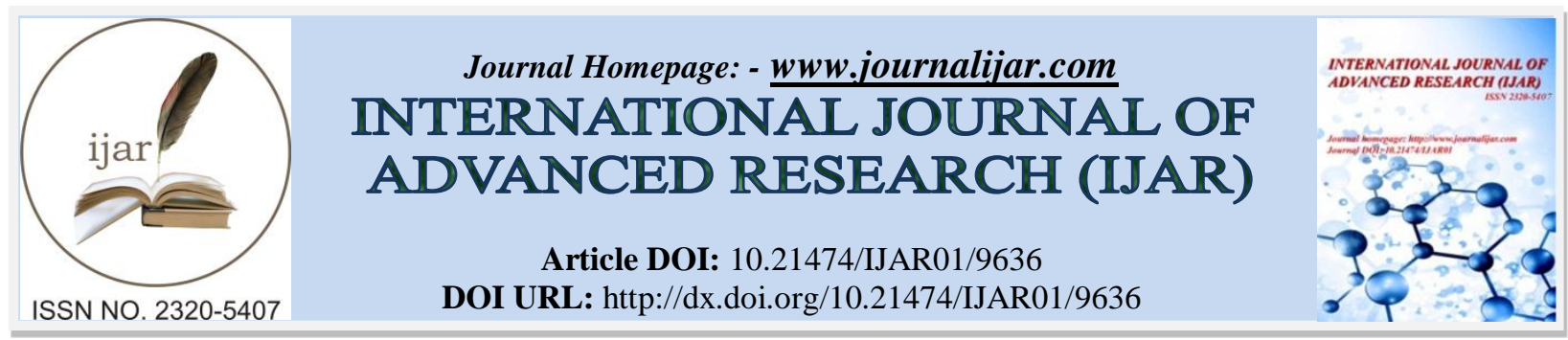

RESEARCH ARTICLE

\title{
ARECA HUSK FIBRES AS AGRO-WASTE TO VALUE ADDED PRODUCTS IN TEXTILE SECTOR - A PRACTICABILITY STUDY.
}

\section{Vasudeva Nayaka K.B.L ${ }^{1}$,Rangaswamy B.E ${ }^{2}$,Tejaswini. ${ }^{3}$, Shrilaxmi Bhat ${ }^{3}$, Sahithya. $G^{3}$ and Annapurna Vajrad ${ }^{3}$.}

1. Assistant Professor Dept. of Biotechnology \& Research Center, Bapuji Instiutute of Engineering \& Technology, Davangere - 577004, Karnataka State, India.

2. Professor \& Head Dept. of Biotechnology \& Research Center, Bapuji Instiutute of Engineering \& Technology, Davangere - 577004, Karnataka State, India.

3. Project associates Dept. of Biotechnology \& Research Center, Bapuji Instiutute of Engineering \& Technology, Davangere - 577004, Karnataka State, India.

\section{Manuscript Info}

Manuscript History

Received: 02 July 2019

Final Accepted: 04 August 2019

Published: September 2019

Key words:-

Cellulase activity on natural fibre, Biosoftening Areca fibres, Enzymatic treatment of natural fibres, Biopolishing in Textile sector.

\begin{abstract}
India continues to be dominating the world in the production and productivity of areca nut and simultaneously with its husk fibres as an unmanaged agro-waste comprehensively. At present, the majority of waste is disposed of by burning which resulted in a loss of the potential source of organic matter and valuable plant nutrients. The areca husk in the plantation causes bad odour and other decay- related problems and poses environmental pollution. This husk can be used as raw material due to its low cost, less weight, low density and biodegradability for the production of value-added products through bio-softening which aims to achieve a polishing effect and avoids the use of caustic chemicals thereby minimizing pollution. The areca nut husk fibres are predominantly composed of cellulose and varying proportions of hemicellulose, lignin, pectin, and proto-pectin. The current study aimed at using cellulase enzyme to act on areca fibres to get fine fibres. These fine fibres obtained through enzymatic treatment can be commercially used in textile industries to produce value-added products blended with an appropriate percentage of cotton.
\end{abstract}

Copy Right, IJAR, 2019,. All rights reserved.

\section{Introduction:-}

Natural fibres are the alternative resource for synthetic fibres. As new natural fibres are in to the limelight, many researchers are contributing new facts about less utilized fibres which may be a fillip for its improvisation. Arecanut husk is one such agro-waste product and it constitutes to $60-80 \%$ of the arecanut fruit by volume. If the husk is not disposed, it starts bio degrading and during this process produces a very bad odour if left unmanaged and poses environmental pollution. The arecanut husk fibres are predominantly composed of cellulose (35-64.8\%) and varying proportions of hemicellulose, lignin (13-26\%), pectin (7\%) and protopectin. Once the softer husk fibre is separated it becomes easy for processing and production of value added products like furnishing fabrics, in textiles by blending with cotton and polyester, thick boards, fluffy cushions and thermal insulators. This husk can be used as raw material for biosoftening through enzyme treatment which brings about softening, thinning and bleaching of the fiber and also avoids the use of caustic chemicals thereby minimizing pollution. The main purpose of using cellulose

Corresponding Author:-Vasudeva Nayaka K.B.L.

Address:-Assistant Professor Dept. of Biotechnology \& Research Center, Bapuji Instiutute of 106 
enzyme in the current study was to get fine and softened areca fibres from low cost, less weight, low density and a biodegradable agro-waste.

\section{Objectives:-}

1. Extraction of fibers from areca husk using cellulose enzyme.

2. Bio-softening with selected enzyme brings about softening, thinning and bleaching of fibers which avoids the use of caustic chemicals minimizing pollution.

3. Cost effective and Eco-friendly processing for separating of areca fibers.

4. Commercial use of Bio-softened areca nut fibers for the use in furnishings, in textile industries and some value added products.

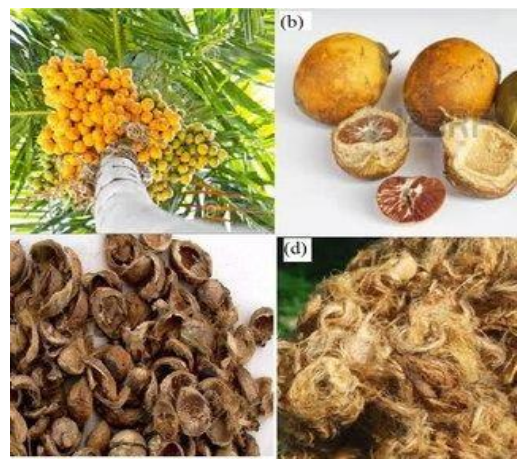

a) Areca nut plant (Areca catechu) b) Areca nut c) Dried areca husk d) Areca husk fibers.

\section{Materials And Methods:-}

\section{Retting:}

The areca husk is loosened by soaking in deionized water in every alternate day with fresh deionized water for about 5 days. Using normal tap water may cause growth of microbes which spoil the husk and influences decaying. The separated fibers are spread on polythene sheet for sun drying for about 3 days.

\section{Alkali Treatment:}

The loosened and sundried areca fibers after retting is subjected for alkali treatment using a solution of $3 \% \mathrm{NaOH}$ at room temperature for about $48 \mathrm{hrs}$. The fibers are then washed with deionized water until to reach neutral $\mathrm{pH}$ and spread over polythene sheet for drying in room temperature for about 72 hours.

\section{Enzymatic Treatment:}

The fibers treated with alkali, washed and dried at room temperature were considered for cellulase enzyme treatment. A suspension of cellulose enzyme powder in distilled water (about $3 \mathrm{~g}$ in $100 \mathrm{ml}$ concentration) was prepared and the areca fibers are soaked providing optimal parameters of $\mathrm{pH} 6.7$ and temperature about $55^{\circ} \mathrm{C}$ required for the cellulase enzyme to on cellulose of the areca fibers for about 60 minutes. Then the areca fibers were washed with deionized water and sundried for 2 days. The procedure was repeated 3 times to ensure cellulose of areca fibers was removed to the maximum extent.

\section{Determination of Cellulose concentration and Cellulase activity on Areca fibers:}

The sample of areca fibers both enzymatically treated and untreated were made a fine powder and a suspension was prepared using deionized water taking $1 \mathrm{~g}, 2 \mathrm{~g} \& 3 \mathrm{~g}$ separately to carry out comparative analysis for the concentration of cellulose in the fibers using standard calibration curve of maltose by Dinitro salicylic acid (DNS) method using colorimeter at $520 \mathrm{~nm}$ followed by cellulase activity determination.

Results And Discussions:Preparation of Standard Maltose (1 mg/ml) Curve.

\begin{tabular}{|c|c|c|c|c|c|c|c|}
\hline $\begin{array}{c}\text { Sl } \\
\text { no. }\end{array}$ & $\begin{array}{c}\text { Std } \\
\text { Maltose }\end{array}$ & $\begin{array}{c}\text { Distille } \\
\text { d water }\end{array}$ & $\begin{array}{c}\text { Conc of } \\
\text { Maltose }\end{array}$ & $\begin{array}{c}\text { DNS } \\
(\mathrm{ml})\end{array}$ & $\begin{array}{c}\text { Rochelle's } \\
\text { Salt (ml) }\end{array}$ & $\begin{array}{c}\text { Optical } \\
\text { Density }\end{array}$ \\
\hline
\end{tabular}




\begin{tabular}{|c|c|c|c|c|c|c|c|}
\hline & $\begin{array}{l}\text { solution } \\
(\mathrm{ml})\end{array}$ & (ml) & $(\mu \mathrm{g})$ & & \multirow{7}{*}{$\begin{array}{l}\text { Heat for } \\
20 \text { min } \\
\text { in water } \\
\text { bath at } \\
55^{\circ} \mathrm{C} \\
\text { and cool }\end{array}$} & & $\begin{array}{c}\text { at } \\
520 \mathrm{~nm}\end{array}$ \\
\hline 1 & 0.0 & 5 & 000 & 1.0 & & 1.0 & 0.00 \\
\hline 2 & 0.2 & 4.8 & 200 & 1.0 & & 1.0 & 0.00 \\
\hline 3 & 0.4 & 4.6 & 400 & 1.0 & & 1.0 & 0.01 \\
\hline 4 & 0.6 & 4.4 & 600 & 1.0 & & 1.0 & 0.07 \\
\hline 5 & 0.8 & 4.2 & 800 & 1.0 & & 1.0 & 0.10 \\
\hline 6 & 1.0 & 4.0 & 1000 & 1.0 & & 1.0 & 0.13 \\
\hline
\end{tabular}

Obtained Standard Maltose Curve

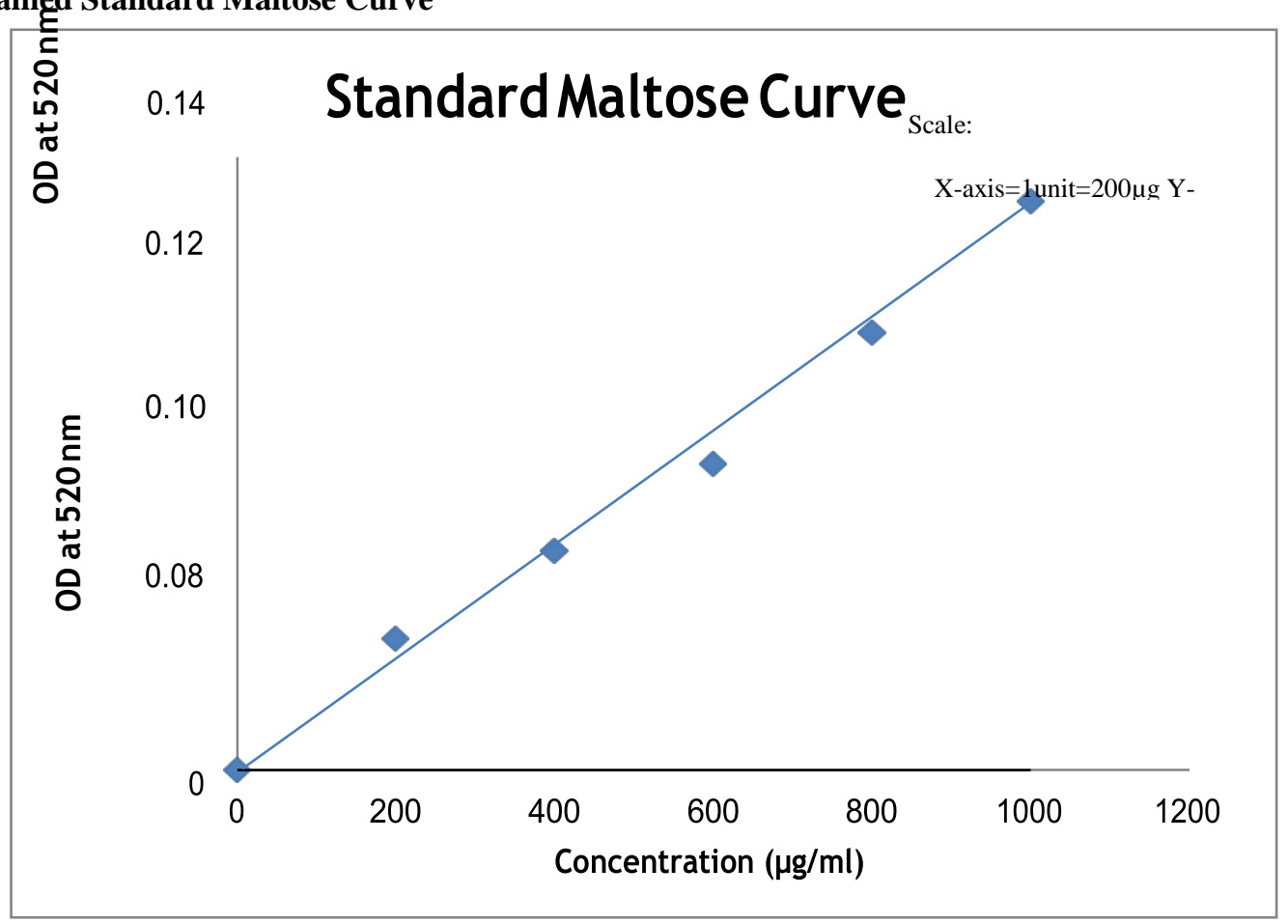

Determination of cellulose concentration in areca fibers powder.

\begin{tabular}{|c|c|c|c|c|c|c|c|}
\hline $\begin{array}{l}\text { S } \\
1 \\
\text { no }\end{array}$ & Test tubes & \multirow[t]{2}{*}{ Incubate at } & $\begin{array}{r}\text { DNS } \\
(\mathrm{ml})\end{array}$ & \multirow{7}{*}{$\begin{array}{l}\text { Heat } \\
\text { in } \\
\text { water } \\
\text { bath } \\
\text { for } 10 \\
\text { min at } \\
55^{\circ} \mathrm{C}\end{array}$} & $\begin{array}{c}\text { Rochelle's } \\
\text { salt } \\
(\mathrm{ml})\end{array}$ & $\begin{array}{l}\mathrm{Dw} \\
(\mathrm{ml})\end{array}$ & $\begin{array}{c}\text { OD at } \\
520 \mathrm{n} \\
\mathrm{m}\end{array}$ \\
\hline \multirow[t]{3}{*}{1} & Control & & 1.0 & & & & \\
\hline & & \multirow{2}{*}{$\begin{array}{l}\text { RT for } 10 \\
\text { minutes with } \\
\text { occasional } \\
\text { shaking }\end{array}$} & & & 1.0 & 5.0 & 0.0 \\
\hline & $\begin{array}{l}\text { Test solution } \\
\text { I) TS-1- } 1 \%\end{array}$ & & 1.0 & & 1.0 & 5.0 & 0.04 \\
\hline \multirow[t]{3}{*}{2} & II) $\mathrm{TS}-2-2 \%$ & & 1.0 & & & & \\
\hline & & & & & 1.0 & 5.0 & 0.08 \\
\hline & III) TS-3- 3\% & & 1.0 & & 1.0 & 5.0 & 0.12 \\
\hline
\end{tabular}




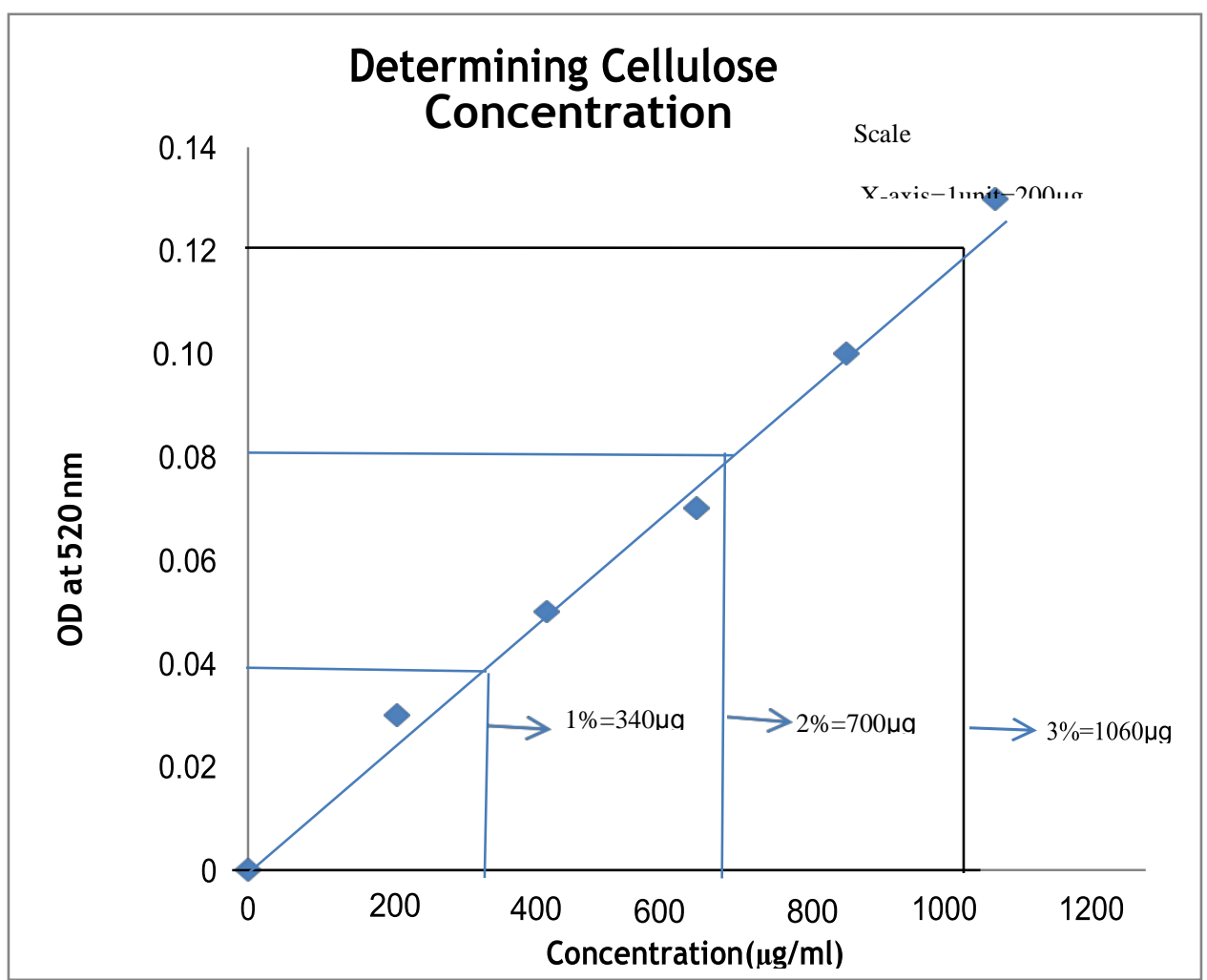

The concentration of cellulose found in areca fiber powder for $1 \%, 2 \%$ and $3 \%$ of sample solution, the $3 \%$ sample solution shown maximum concentration of cellulose of about 1 milligram.

Determination of cellulase activity on $3 \%$ sample solution of areca fibers powder.

\begin{tabular}{|c|c|c|c|c|c|c|c|}
\hline $\begin{array}{r}\text { S1 } \\
\text { No }\end{array}$ & Test tubes & \multirow{3}{*}{$\begin{array}{l}\text { Incubate at } \\
\text { room temp } \\
\text { for } 10 \mathrm{~min} \\
\text { with } \\
\text { occasional } \\
\text { shaking }\end{array}$} & $\begin{array}{c}\text { DNS } \\
(\mathrm{ml})\end{array}$ & \multirow{3}{*}{$\begin{array}{l}\text { Heat in } \\
\text { water } \\
\text { bath for } \\
10 \mathrm{~min} \\
\text { at } 55^{\circ} \mathrm{C} \\
\text { and } \\
\text { cooled }\end{array}$} & $\begin{array}{l}\text { Rochell's } \\
\text { salt (ml) }\end{array}$ & $\begin{array}{c}\text { D. } \\
\text { water } \\
\text { (ml) }\end{array}$ & $\begin{array}{l}\text { OD at } \\
520 \mathrm{~nm}\end{array}$ \\
\hline 1 & $\begin{array}{l}\text { Control } \\
\text { without } \\
\text { cellulase }\end{array}$ & & 1.0 & & 1.0 & 5.0 & 0.0 \\
\hline 2 & $\begin{array}{c}\text { Test } \\
\text { solution } \\
(1.0 \mathrm{ml} 3 \% \\
\text { sample } \\
\text { solution } \\
\text { and } 1.0 \mathrm{ml} \\
\text { cellulase of } \\
3 \mathrm{mg} / \mathrm{ml} \\
\text { conc.) }\end{array}$ & & 1.0 & & 1.0 & 5.0 & 0.01 \\
\hline
\end{tabular}




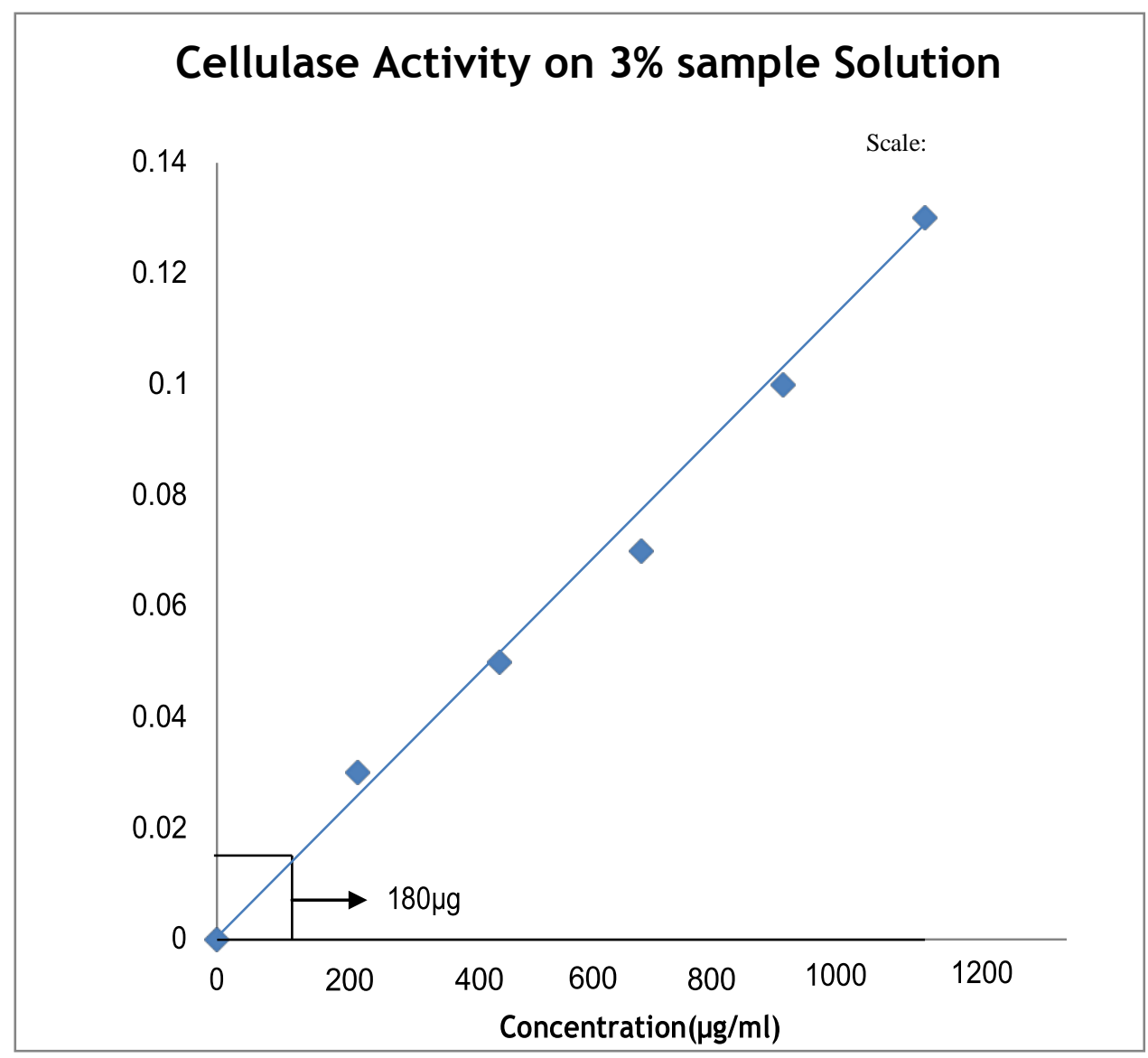

Cellulase Activity $=[$ Enzyme concentration found $/$ Mol.wt of cellulose*incubation time]*DF Where; Molecular weight of cellulose $=162.14 \mathrm{gm} / \mathrm{mol}$, Incubation time $=10 \mathrm{~min}$, Dilution factor $=10$

Cellulase activity $=[180 / 162.14 * 20] * 10$

A. $=0.55 \mathrm{ku}$

\section{Discussions:-}

The alkali treated areca fibers when treated with cellulase enzyme, the obtained fibers without cellulose was reduced up to $50 \%$ of total mass and become much softened fibres after sundried for 8 hours for 2 days. The whole procedure of determining the cellulase enzyme activity before and after enzymatic treatment of areca fibers was evident with the study results that around $1 \mathrm{mg}$ of cellulose was removed per $3 \%$ of areca fiber powder used

\section{Conclusion:-}

Overall studies with enzymatic treatment of areca husk fibers which was the main objective of our project given us the positive results that established more polished and biosoftened fibers. This can be considered to manufacture a value added products by blending with appropriate percent of cotton (up to 40\%) in textile industries. Although the study on physical characteristics of a thread to use in industrial scale pose challenges to be addressed which paves the way for added scope of research in that line. As an agrowaste, arecanut husk can be recycled by the methods discussed and substantiated with results could give us an eco- friendly, biodegradable and cost effective value added product.

\section{References:-}

1. Akhila Rajan, Jayalakshmi Gopinadha Kurup, Tholath Emilia Abraham, Biosoftening of arecanut fiber for value added products Received 21 September 2004; received in revised form 13 April 2005; accepted 31 May 
2005. Biochemical Engineering Journal 25 (2005) 237-242.

2. C.V. Srinivasa, K.N. Bharath, Impact and Hardness Properties of Areca Fiber-Epoxy Reinforced Composites, Received in 27 May 2011, Revised 3 Aug 2011, Accepted 3 Aug 2011. J. Mater. Environ. Sci. 2 (4) (2011) 351356.

3. S.K. Ghosh, M.K.Sinha, S.B. Bandopadhya, An attempt for the use of arecanut husk fiber for textile purposes, J.Plant crops 3 (1975) 29-33.

4. Raghuveer H. Desai1, L. Krishnamurthy, T. N. Shridhar, Lighting and Effectiveness of Areca (Betel) Fiber as a Reinforcing Material in Eco-friendly Composites: A Review, Received 7th February 2016; Revised 9th May 2016; Accepted $16^{\text {th }}$ May 2016.

5. Divya sundarraj \& s. Grace annapooran, development of non-woven fabric using areca husk for textile application, Journal of Textile and Fashion Technology (JTFT) Vol.5, Issue 1, Jun 2015, 1-6.

6. Narendra Reddy and Yiqi Yang- Biofibers from agricultural byproducts for industrial applications.Department of textiles, Clothing and design, Published online November 20, 2004.

7. Nagaraja, B. R. Gurumurthy \& M. B. Shivanna, bio softening of arecanut waste areca husk, leaf and leaf sheath for value added compost, impact: InternationalJournal of Research in Applied, Natural and Social Sciences (IMPACT: IJRANSS) ISSN(E): 2321-8851; ISSN(P): 2347-4580 Vol. 2, Issue 9, Sep 2014, 105-112.

8. L. Yusriah a, S.M. Sapuan a, E.S. Zainudin b, M. Mariatti c. Characterization of physical, mechanical, thermal and morphological properties of agro-waste betel nut (Areca catechu) husk fibre. Article history: Received 26 October 2013 Received in revised form 28 January 2014 Accepted 7 February 2014 Available online 12 March 2014.

9. Farjan islam, Narayan roy, Screening, purification and characterization of cellulase from cellulase producing bacteria in molasses. Received: 29 May 2018 Accepted: 29 June 2018Published: 4 July 2018.

10. Y Karaduman, D Gokcan, L Onal . Effect of enzymatic pretreatment on the mechanical properties of jute fiberreinforced polyester composites , First Published May 22, 2012

11. Y Karaduman, L Onal, Dynamic mechanical and thermal properties of enzyme- treated jute/polyester composites, First Published August 29, 2012

12. Yingwang, yulinzhao, yulindeng .Effect of enzymatic treatment on cotton fiber dissolution in naoh/urea solution at cold temperature, Volume 72, Issue 1, 3 April 2008, Pages 178-184

13. Jianchen' qiangwang zhaozhehua, guochengdu . Research and application of biotechnology in textile industries in China, Volume 40, Issue 7, 1 June 2007, Pages 1651-1655

14. Dieter Klemm Prof. Dr. Brigitte Heublein Dr. Hans-Peter Fink Dr. Habil. Andreas Bohn, Cellulose: Fascinating Biopolymer and Sustainable Raw Material..First published: 24 May 2005.

15. Takwai E.Lai Pratap C.Pullammanappalli William P.Clarke, Quantification of cellulase activity using cellulose-azure Volume 69, Issue 1, 15 March 2006, Pages 68- 72

16. Danny eakin Jonn afoulk Roy bdodd David dmcalisteriii . Enzyme-retting of flax and characterization of processed fibers, Journal of Biotechnology Volume 89, Issues 2- 3, 23 August 2001, Pages 193-203.88

17. Marek Jan,Antonov Viktor, Fischer holger, Enzymatic Bioprocessing - New Tool of Extensive Natural Fibre Source Utilization, July 2008

18. F. Zbidi, S. Sghaier, M.B. Nejma and M. Zidi, 2009. Influence of Alkaline and Enzymatic Treatments on the Properties of Doum Palm Fibres and Composite. Journal of Applied Sciences, 9: 366-371.

19. Mohammad Shahid, Faqeer Mohammad, Guoqiang Chen, Ren-Cheng Tang and Tieling Xing Enzymatic processing of natural fibres: white biotechnology for sustainable development, received on 20 Jan 2016, accepted on 29 Feb 2016 and first published on 01 Mar 2016, Green Chem.,2016,18,2256-2281. 